EDITORIAL

\title{
Homenagem a Beth Pompêo
}

$\mathcal{A}$

trajetória acadêmica de Beth Pompêo é marcada pelo rigor intelectual e pela busca da perfeição na pesquisa, pelo compromisso com a educação brasileira e pela visão a respeito do importante papel desempenhado pela atividade editorial na difusão do conhecimento científico.

O interesse da pesquisa empreendida por Beth sobre Fernando de Azevedo é estratégico, o que se evidencia no recorte sobre educação física, na sua tese de mestrado.

Com o intuito de analisar a contribuição de Fernando de Azevedo para a educação brasileira, tomou como referência $A$ poesia do corpo, de 1915. Mas ela também trabalhou com todo o material do autor no período entre 1915 e 1974, para interpretar rigorosamente suas idéias principais. Não satisfeita com isso, estudou seu percurso familiar, intelectual e profissional, em uma pesquisa importante sobre o pensamento social brasileiro. Partindo da concepção de que toda visão de mundo é situada, Beth Pompêo analisou as experiências vividas pelo seu personagem em diferentes contextos e momentos históricos de sua trajetória.

Por meio de seus estudos, ela evidencia que a moral austera de Fernando de Azevedo, embutida na proposta de adoção da educação física nos currículos escolares como parte essencial da formação dos jovens, em nome da eugenia, devia-se a uma concepção racionalista, adicionada a uma moral vitoriana, conforme o pensamento dominante do final do século XIX e das primeiras décadas do século XX.

Neste particular, seu trabalho contribui para o entendimento das bases do pensamento da educação brasileira na primeira metade do século XX. A relação entre a produção intelectual e a política da educação, cerne das suas preocupações, fundamenta o modo como as políticas são feitas por homens concretos nos diferentes períodos da História.

$\mathrm{O}$ rigor metodológico de Beth vai além da pesquisa exaustiva de dados primários coletados principalmente no Arquivo Histórico Mineiro e 
no Colégio Estadual Governador Milton Campos. Além deles, a investigação bibliográfica mostra sua preocupação de registrar todas as referências possíveis ligadas ao seu tema, muitos dos autores seus amigos pessoais.

Como exemplo desse trabalho acadêmico de magnitude e como homenagem póstuma, Educação \& Sociedade publica, neste número, um dos capítulos da dissertação de Beth, tratando da análise que Fernando de Azevedo fez do fenômeno do "rebaixamento moral", em curso no país naquelas primeiras décadas do século XX.

A professora Beth deixou também sua marca na criação do Departamento de Sociologia da Educação, da Faculdade de Educação da UNICAMP, e na sua posterior transformação em Ciências Sociais Aplicadas à Educação. Da sociologia geral à sociologia da educação e às políticas educacionais, foi presença integrante na formação dos pedagogos dessa Faculdade, expandindo sua atuação acadêmica ao âmbito nacional.

Esse caminho ela o traça, ao lado de colegas, no âmago de uma pesquisa sobre a "Análise de currículo e conteúdo programático dos cursos de pedagogia, com vistas a propostas alternativas de reformulação", coordenada no Departamento de Sociologia da Educação, da Faculdade de Educação da UNICAMP, com a participação de pesquisadores de vários departamentos e financiada pelo Instituto Nacional de Estudos e Pesquisas Educacionais (INEP) (1977/1979). Essa pesquisa se destaca nacionalmente com a realização, em sua última etapa, do I Seminário de Educação Brasileira (20 a 22 de novembro de 1978, na FE/UNICAMP, em Campinas), sobre a temática "A função e a estrutura da pedagogia na educação brasileira", evento reconhecido na história da educação como o primeiro movimento nacional organizado por educadores após o golpe militar de 1964. Ademais, a referida pesquisa, no interior do movimento histórico de reconstrução democrática do país, nos anos de 1980, foi o estopim de mudanças curriculares do curso de pedagogia em várias universidades do país.

A pesquisa e os movimentos de mudança do e no campo da educação trazem em suas origens outro prisma da atuação da Beth que se destaca admiravelmente. Apreendendo a importância do momento político do país e a necessidade de se construir uma sociedade democrática, a professora foi particularmente atenta à difusão do conhecimento gerado no campo das pesquisas educacionais, produção esta decorrente, sobretudo, da recém-criada área da pós-graduação e das necessárias mudanças sociais. A propósito das "Novas Revistas" (seção sob sua responsabilidade), Beth expressa-se pontuando que 
A necessidade de uma análise mais profunda das contradiçôes da sociedade brasileira e das principais questôes que estão sendo colocadas para o debate político atual tem feito com que a intelectualidade mais conseqüente do país procure criar novos veículos de difusão de análises teóricas relevantes, as quais têm sido publicadas não só em livros como em cadernos de debates, jornais e revistas. Um estudo do movimento editorial recente poderá revelar o aparecimento de uma significativa produção cultural, o que demonstra que muitos intelectuais brasileiros, lutando contra a repressão e as limitaçôes impostas ao seu trabalho, têm conseguido exercer uma função crítica na análise da formação social brasileira, procurando abordar temáticas importantes, em que a questão da democracia aparece como central, ao mesmo tempo que passa a exigir interpretações mais profundas. (Educação \& Sociedade, ano I, n. 1, p. 203, 1978)

Pode-se considerar como uma das características do campo educacional nos anos de 1960/1970 a circulação de poucas revistas e a dimensão inatingível da manutenção de suas periodicidades. Entretanto, a professora empenha-se, ao lado de outros pesquisadores da Faculdade de Educação, na criação de um novo periódico. Surge, então, em setembro de 1978, o número 1 de Educação \& Sociedade, revista quadrimestral de Ciências da Educação, focando o tema "O educador precisa ser educado" e registrando em suas páginas iniciais o seu compromisso:

(...) análise da realidade educacional brasileira, (...) tanto no que se refere a técnicas, doutrinas e práticas educacionais como no que se refere à reflexão sobre o seu impacto na sociedade como um todo (...), tendo como foco a perspectiva da teoria e da prática no âmbito do conhecimento socioeducativo, (...) (associando) informação histórica (...) aos problemas colocados pela educação brasileira contemporânea.

Lançada nacionalmente nos calçadões de Brasília, com a presença da Beth, seu relançamento ocorreu no I Seminário de Educação Brasileira. Seguiu-se uma bela trajetória, com a participação constante da Beth, até os dias de hoje, de continuidade de Educação \& Sociedade e de afirmação e manutenção da sua periodicidade, contrariamente à efemeridade, característica de várias revistas lançadas naquela década. No rastro da aceitação da revista e incorporando sua perspectiva de ser uma publicação de caráter nacional, deu-se a criação do Centro de Estudos Educação e Sociedade (CEDES), anunciada em seu segundo número, do qual a professora participou ativamente, ocupando várias posições em sua diretoria e, na ocasiāo de sua morte, a vice-presidência.

Cabe, ainda, destacar o compromisso constante da Beth para com o CEDES. Ela integrou diferentes diretorias, ocupando cargos diversos e 
participou ativamente das ações institucionais nas diferentes dimensões da sociedade brasileira. Ressalta-se nos anos de 1980 sua importante presença na organização da série das seis Conferências Brasileiras de Educação, como também sua participação na qualidade de pesquisadora em atividades principais e painéis desses eventos nacionais, que foram significativos para a educação brasileira, marcando, toda a série, forte debate sobre as políticas públicas da educação.

Ainda cabe ressaltar, dentre as ações da Beth acadêmica e política, sua importante participação na Constituinte, representando o CEDES no Fórum Nacional em Defesa da Escola Pública e Gratuita.

A importância do trabalho erudito, a prática pedagógica exemplar, a participação na construção de uma grande universidade e as dimensões do seu trabalho na educação brasileira, à qual ela serviu incansavelmente, dão-nos a dimensão da vida acadêmica da Beth. A Beth intelectual deixou um belo contributo para o pensamento social e para a educação. Por semelhante motivo, os integrantes do CEDES e da UNICAMP, e todos os que militam no campo educacional brasileiro, podem dizer com orgulho e alegria: Beth não nos deixou. 